\title{
Systemic Inflammation Is Associated With Neurologic Involvement in Pediatric Inflammatory Multisystem Syndrome Associated With
} SARS-CoV-2

Neurol Neuroimmunol Neuroinflamm 2021;8:e1023. doi:10.1212/NXI.0000000000001023

In the article "Systemic Inflammation Is Associated With Neurologic Involvement in Pediatric Inflammatory Multisystem Syndrome Associated With SARS-CoV-2” by Sa et al., " the first sentence under Results in the Abstract should read, " 75 patients with PIMS-TS were identified, 9 (12\%) had neurologic involvement: altered consciousness (3), behavioral changes (3), focal neurology deficits (2), persistent headaches (2), hallucinations (2), excessive sleepiness (1), and new-onset focal seizures (1)." The authors regret the error.

\section{Reference}

1. Sa M, Mirza L, Carter M, et al. Systemic inflammation is associated with neurologic involvement in pediatric inflammatory multisystem syndrome associated with SARS-CoV-2. Neurol Neuroimmunol Neuroinflamm. 2021;8(4):e999. doi:10.1212/NXI. 0000000000000999 


\section{Neurology \\ Neuroimmunology \& Neuroinflammation}

\section{Systemic Inflammation Is Associated With Neurologic Involvement in Pediatric Inflammatory Multisystem Syndrome Associated With SARS-CoV-2 \\ Neurol Neuroimmunol Neuroinflamm 2021;8; \\ DOI 10.1212/NXI.0000000000001023}

This information is current as of May 21, 2021

Updated Information \&

Services

References

Permissions \& Licensing

Reprints including high resolution figures, can be found at:

http://nn.neurology.org/content/8/4/e1023.full.html

This article cites 1 articles, 1 of which you can access for free at: http://nn.neurology.org/content/8/4/e1023.full.html\#\#ref-list-1

Information about reproducing this article in parts (figures,tables) or in its entirety can be found online at:

http://nn.neurology.org/misc/about.xhtml\#permissions

Information about ordering reprints can be found online: http://nn.neurology.org/misc/addir.xhtml\#reprintsus

Neurol Neuroimmunol Neuroinflamm is an official journal of the American Academy of Neurology.

Published since April 2014, it is an open-access, online-only, continuous publication journal. Copyright $($ ) 2021 American Academy of Neurology. All rights reserved. Online ISSN: 2332-7812.

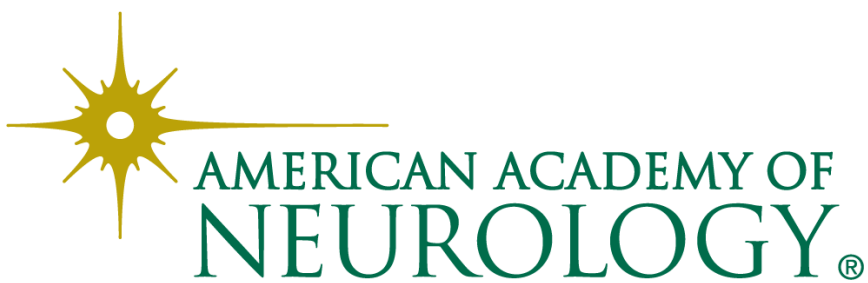

